\title{
KEBERADAAN PERATURAN DAERAH KHUSUS DAN QANUN DALAM PENYELENGGARAAN KEHIDUPAN MASYARAKAT
}

\author{
${ }^{1}$ Ardenolis, ${ }^{\mathbf{2}}$ Busrianto \\ 1,2 Program Pascasarjana Magister Hukum Universitas Lancang Kuning \\ Email: ${ }^{1}$ arethenolist@gmail.com ${ }^{2}$ busrianto79@ gmail.com
}

Info Artikel:

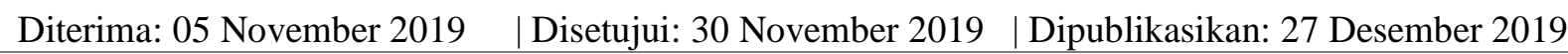

\begin{abstract}
Abstrak
Peraturan Daerah Khusus dan Qanun merupakan peraturan perundang-undangan yang sejenis dengan Peraturan Daerah, maka kedudukan Peraturan Daerah Khusus dan Qanun setingkat dengan Peraturan Daerah. Berbeda halnya dengan Qanun, Peraturan Daerah Khusus hanya terdapat pada tingkatan Provinsi dan kedudukannya setingkat dengan Peraturan Daerah Provinsi. Penelitian ini merupakan penelitan hukum normatif. Dalam Undang-Undang Nomor 10 Tahun 2004 menyatakan bahwa jenis dan hierarki peraturan perundang- undangan sebagai berikut: Undang-Undang Dasar Negara Republik Indonesia Tahun 1945, Undang-Undang/Peraturan Pemerintah Pengganti Undang-Undang, Peraturan Pemerintah, Peraturan Presiden dan Peraturan Daerah. Dalam Penjelasan Pasal 7 menegaskan bahwa termasuk dalam jenis peraturan daerah provinsi adalah Qanun yang berlaku di Daerah Provinsi Nanggroe Aceh Darussalam dan Peraturan Daerah Khusus serta Peraturan Daerah Provinsi yang berlaku di Provinsi Papua.
\end{abstract}

Kata Kunci: Peraturan Daerah Khusus, Qanun

\section{THE EXISTENCE OF SPECIAL REGIONAL REGULATIONS AND QANUN IN THE IMPLEMENTATION OF COMMUNITY LIFE}

\begin{abstract}
Special Regional Regulations and Qanun are statutory regulations similar to Regional Regulations, so the position of Special Regional Regulations and Qanun is at the same level as Regional Regulations. Unlike the case with Qanun, Special Regional Regulations only exist at the provincial level and their position is at the same level as the Provincial Regulations. This research is a normative legal research. Law Number 10 of 2004 states that the types and hierarchies of statutory regulations are as follows: the 1945 Constitution of the Republic of Indonesia, Laws/Government Regulations in Lieu of Laws, Government Regulations, Presidential Regulations and Regional Regulations. The Elucidation of Article 7 confirms that included in the types of provincial regulations are Qanun that apply in the Province of Nanggroe Aceh Darussalam and Special Regional Regulations and Provincial Regulations that apply in Papua Province.
\end{abstract}

Keywords: Special Regional Regulation, Qanun

Jurnal Gagasan Hukum Vol. 01 | No.02 | Desember 2019 


\section{A. PENDAHULUAN}

Amandemen Undang-Undang Dasar Negara Republik Indonesia Tahun 1945 membawa banyak perubahan pada sistem politik dan sistem ketatanegaraan di Indonesia. ${ }^{1}$ Salah satu perubahan mendasar yang dilahirkan ialah perubahan dalam sistem penyelenggeraan pemerintahan daerah. Paradigma politik ketatanegaraan yang semula cenderung bernuansa otoritarian berubah menjadi lebih demokratis. Pola kekuasaan eksekutif yang terpusat dan terlalu dominan diakui sebagai pola yang kurang mendukung dalam mewujudkan kesejahteraan yang merata bagi masyarakat di Indonesia. Seiring derasnya tuntutan masyarakat, penerapan pola pemerintahan yang sentralistik semakin tidak relevan dengan situasi, kondisi, dan perkembangan kehidupan masyarakat sehingga perubahan ke arah demokratisasi dan desentralisasi menjadi suatu hal yang mutlak.

Dalam konteks hubungan antara pusat dengan daerah, sistem penyelenggaraan pemerintahan daerah bergeser dari sistem yang sentralistik menjadi sistem yang mengedepankan otonomi dengan berpijak pada prinsip desentralisasi. Penerapan prinsip desentralisasi sebagai dasar berpijak penyelenggaraan pemerintahan daerah membangun konstelasi baru sistem otonomi

\footnotetext{
${ }^{1}$ Undang-Undang Dasar Negara Republik Indonesia Tahun 1945.
}

daerah yang luas, nyata, dan bertanggung jawab yang memberikan hak dan wewenang kepada daerah otonom untuk mengatur dan mengurus sendiri urusan pemerintahan dan kepentingan masyarakat setempat sesuai dengan peraturan perundang-undangan.

Dalam lintasan sejarah, setelah 25 Tahun mengawal perjalanan penyelenggaraan pemerintahan daerah di Indonesia, Undang-Undang Nomor 5 Tahun 1974 tentang Pemerintahan di Daerah yang cenderung bersifat sentralistik digantikan dengan Undang-Undang Nomor 22 Tahun 1999 tentang Pemerintahan Daerah. Namun, Undang-Undang Nomor 22 Tahun 1999 tidak lama lama bertahan sebab dibentuk dengan semangat kebebasan yang begitu tinggi di tengah memuncaknya euforia reformasi sehingga banyak pengaturan yang tidak proporsional dan cenderung mengarah pada otonomi yang kebablasan. Pada perkembangan lebih lanjut, Undang-Undang Nomor 22 Tahun 1999 tentang Pemerintahan Daerah diganti dengan Undang-Undang Nomor 32 Tahun 2004 tentang Pemerintahan Daerah sebagai langkah perbaikan dan penyempurnaan atas kelemahan yang terdapat dalam UndangUndang Nomor 22 Tahun 1999. ${ }^{2}$

Hal yang mendasar dari adanya perubahan undang-undang tersebut ialah

\footnotetext{
${ }^{2}$ Undang-Undang Nomor 22 Tahun 1999 tentang Pemerintahan Daerah diganti dengan Undang- Undang Nomor 32 Tahun 2004 tentang Pemerintahan Daerah.
} 
memberikan kesempatan dan kekuasaan daerah untuk membangun daerahnya dan lebih memberdayakan masyarakat, menumbuhkan prakarsa dan kreativitas serta meningkatkan peran dan fungsi Dewan Perwakilan Rakyat Daerah. Daerah otonom diberikan hak dan wewenang untuk mengatur dan mengurus sendiri urusan pemerintahan dan kepentingan masyarakat setempat sesuai dengan peraturan perundang-undangan. Kewenangan pengaturan ini adalah kewenangan bagi daerah untuk membentuk Peraturan Daerah.

Secara konstitusional Pasal 18 ayat (6) Undang-Undang Dasar Negara Republik Indonesia Tahun 1945 (Perubahan Kedua) menyatakan bahwa pemerintahan daerah berhak menetapkan peraturan daerah dan peraturan- peraturan lain untuk melaksanakan otonomi dan tugas pembantuan. Kemudian Pasal 136 ayat (1) junto ayat (2) Undang-Undang Nomor 32 Tahun 2004 mengatur bahwa Peraturan Daerah ditetapkan oleh Kepala Daerah setelah mendapat persetujuan bersama Dewan Perwakilan Rakyat Daerah dibentuk dalam rangka penyelenggaraan otonomi daerah provinsi/kabupaten/kota dan tugas pembantuan.

Seiring dengan itu, pengakuan dan penghormatan atas satuan-satuan pemerintahan daerah yang bersifat khusus atau istimewa, di era pasca reformasi mendapat porsi lebih daripada era sebelumnya. Pasal 18B Undang-Undang Dasar Negara Republik Indonesia Tahun 1945 yang merupakan hasil dari Amandemen Kedua menyatakan: Negara mengakui dan menghormati satuan-satuan pemerintahan daerah yang bersifat khusus atau bersifat istimewa yang diatur dengan undang- undang; Negara mengakui dan menghormati kesatuan- kesatuan masyarakat hukum adat beserta hak-hak tradisionalnya sepanjang masih hidup dan sesuai dengan perkembangan masyarakat dan prinsip Negara Kesatuan Republik Indonesia, yang diatur dalam undangundang.

Berangkat hal tersebut, lahirlah Undang-Undang Nomor 18 Tahun 2001 tentang Otonomi Khusus bagi Provinsi Daerah Istimewa Aceh sebagai Provinsi Nanggroe Aceh Darusalam yang selanjutnya diganti dengan Undang-Undang Nomor 11 Tahun 2006 tentang Pemerintahan Aceh, ${ }^{3}$ dan Undang-Undang Nomor 21 Tahun 2001 tentang Otonomi Khusus bagi Propinsi Papua. ${ }^{4}$

Hubungan Pemerintah Pusat dan Daerah telah diatur dalam Pasal 18 Undang-Undang Dasar Negara Republik Indonesia Tahun 1945 yang kemudian pasal ini diamandemen oleh Majelis

\footnotetext{
${ }^{3}$ Undang-Undang Nomor 18 Tahun 2001 tentang Otonomi Khusus bagi Provinsi Daerah Istimewa Aceh diganti dengan Undang-Undang Nomor 11 Tahun 2006 tentang Pemerintahan Aceh.

4 Undang-Undang Nomor 21 Tahun 2001 tentang Otonomi Khusus bagi Propinsi Papua.
} 
Permusyawaratan Rakyat pada tanggal 18 Agustus 2000. Pasal 18 ayat (1) UUD 45 menegaskan bahwa Negara Kesatuan Republik Indonesia dibagi atas daerahdaerah provinsi dan daerah provinsi itu dibagi atas kabupaten dan kota, yang tiaptiap provinsi, kabupaten, dan kota itu mempunyai Pemerintahan Daerah, yang diatur dengan undang-undang. Menurut Jimly Asshiddiqie, istilah "dibagi atas" dimaksudkan untuk menegaskan bahwa hubungan antara Pemerintah Pusat dan Daerah bersifat hirarkis dan vertikal. ${ }^{5}$

Adapun tentang hubungan antara Pemerintah Pusat dan Pemerintah Daerah terdapat di dalam ketentuan Pasal 18 A ayat (1) yang mengatakan bahwa Hubungan wewenang antara Pemerintah Pusat dan Pemerintahan Daerah provinsi, kabupaten, dan kota, atau antara provinsi dan kabupaten dan kota, diatur dengan undangundang dengan memperhatikan kekhususan dan keragaman daerah. Jimly Asshiddiqie menjelaskan, bahwa yang dimaksud dengan "kekhususan daerah" adalah kekhususan atau keistimewaan yang terdapat di masingmasing daerah, sedangkan keragaman daerah adalah keragaman antar daerah yang

5 Jimly Asshiddiqie, Konsolidasi Naskah UUD 1945 Setelah Perubahan Keempat, (Jakarta: Pusat Studi Hukum Tata Negara, FH UI, 2002), hlm. 21. satu dengan daerah lain yang masingmasing berbeda-beda satu sama lain. ${ }^{6}$

Adanya otonomi daerah itulah yang mengakibatkan daerah berlomba-lomba untuk mengatur segala urusan yang berkaitan dengan daerahnya ke dalam Peraturan Daerah, terutama Peraturan Daerah tentang pajak daerah dan retrebusi daerah. Di sisi yang lain, ada sebagian masyarakat di daerah yang menghendaki daerahnya melahirkan Peraturan DaerahPeraturan Daerah yang bernuansa syariah semakin marak, sehingga menimbulkan sikap pro dan kontra. ${ }^{7}$

Berkenaan dengan pelaksanaan otonomi khusus, Pemerintahan Aceh dan Provinsi Papua tersebut dibutuhkan pula peraturan daerah yang bersifat khusus bagi daerah otonomi khusus tersebut. Aceh sebagai daerah otonomi khusus, sesuai dengan Undang-Undang Nomor 11 Tahun 2006 memiliki peraturan daerah yang bersifat khusus pula, yaitu Qanun Aceh dan Qanun Kabupaten/Kota. Qanun Aceh adalah peraturan perundang-undangan sejenis peraturan daerah provinsi yang mengatur penyelenggaraan pemerintahan dan kehidupan masyarakat Aceh, sedangkan Qanun Kabupaten/Kota ialah

\footnotetext{
${ }^{6}$ Ibid., hlm. 23.

7 Muhammad Alim, "Perda Bernuansa Syariah Dan Hubungannya Dengan Konstitusi", Jurnal Hukum Ius Quia Iustum, FH UII, No.1 Vol. 17 Januari 2010, hlm. 120.
} 
peraturan perundang-undangan sejenis peraturan daerah kabupaten/kota yang mengatur penyelenggaraan pemerintahan dan kehidupan masyarakat kabupaten/kota di Aceh.

Begitu pula Provinsi Papua sebagai daerah otonomi khusus, sesuai dengan Undang-Undang Nomor 21 Tahun 2001, selain memiliki Peraturan Daerah, juga memiliki instrumen hukum tersendiri dalam mengatur daerahnya yaitu Peraturan Daerah Khusus dan Peraturan Daerah Istimewa. Peraturan Daerah Khusus, yang selanjutnya disebut Perdasus adalah Peraturan Daerah Provinsi Papua dalam rangka pelaksanaan pasal-pasal tertentu dalam Undang-Undang Nomor 21 Tahun 2001, sedangkan Peraturan Daerah Provinsi, yang selanjutnya disebut Perdasi adalah Peraturan Daerah Provinsi Papua dalam rangka pelaksanaan kewenangan sebagaimana diatur dalam peraturan perundang-undangan.

Berdasarkan uraian latar belakang masalah tersebut dapat dirumuskan pokok permasalahan sebagai berikut: Bagaimanakah kedudukan Peraturan Daerah Khusus dan Qanun? Bagaimanakah materi muatan Peraturan Daerah Khusus dan Qanun, dan Bagaimanakah keberadaan Peraturan Khusus dan Qanun dalam penyelenggaraan pemerintahan dan kehidupan masyarakat?

\section{B. METODE PENELITIAN}

Jenis penelitian ini adalah penelitian hukum normatif, yakni penelitian berdasarkan kaidah hukum yang berlaku. Jenis penelitian hukum normatif bersifat penelitian hukum kepustakaan, ${ }^{8}$ sebab penelitian ini menjadikan bahan kepustakaan sebagai penopang utama. Dalam penelitian hukum normatif penelitian dilakukan terhadap asas-asas hukum yang bertitik tolak dari bidangbidang tata hukum tertentu dan melakukan identifikasi terhadap berbagai kaidah hukum yang telah dirumuskan di dalam perundang-undangan tertentu. ${ }^{9}$

\section{HASIL DAN PEMBAHASAN}

\section{Kedudukan Peraturan Daerah}

\section{Khusus dan Qanun}

Pemahaman mengenai kedudukan Peraturan Daerah Khusus dan Qanun berkaitan dengan bagaimana memahami Peraturan Daerah sebagai bagian dari sistem hukum nasional yang tercermin dalam konstruksi jenis dan hirarki Peraturan Perundang-Undangan. Sedangkan hierarki adalah penjenjangan setiap jenis peraturan perundang-undangan yang didasarkan pada asas bahwa peraturan perundang-undangan yang lebih rendah tidak boleh bertentangan dengan peraturan perundang-undangan yang lebih tinggi. Jenis dan hirarki

${ }^{8}$ Soerjono Soekanto dan Sri Mamudji, Penelitian Hukum Normatif, Suatu Tinjauan Singkat, (Jakarta: Raja Grafindo, 2003), hlm 23.

${ }^{9}$ Ibid., hlm. 15. 
peraturan perundang-undangan diatur dalam Pasal 7 Undang-Undang Nomor 10 Tahun 2004 tentang Pembentukan Peraturan Perundang-undangan sebagaimana telah diubah dengan Undang-Undang Republik Indonesia Nomor 12 Tahun 2011 tentang Pembentukan Peraturan Perundang-Undangan. Berdasarkan Pasal 7 ayat (1) dengan Undang-Undang Republik Indonesia Nomor 12 Tahun 2011 tentang Pembentukan Peraturan PerundangUndangan, Jenis dan hierarki Peraturan Perundang-undangan terdiri atas:

1. Undang-Undang Dasar Negara Republik Indonesia Tahun 1945

2. Ketetapan Majelis Permusyawaratan Rakyat

3. Undang-Undang/Peraturan Pemerintah Pengganti Undang-Undang

4. Peraturan Pemerintah

5. Peraturan Presiden

6. Peraturan Daerah Provinsi

7. Peraturan Daerah Kabupaten/Kota. ${ }^{10}$

Selanjutnya dalam ayat (2) kekuatan hukum peraturan perundang-undangan sesuai dengan hierarki sebagaimana dimaksud pada ayat (1) menyatakan bahwa Peraturan Daerah sebagaimana dimaksud pada ayat (1) huruf e meliputi:

1. Peraturan Daerah provinsi dibuat oleh dewan perwakilan rakyat daerah provinsi bersama dengan gubernur;

10 Undang-Undang Nomor 10 Tahun 2004 tentang Pembentukan Peraturan Perundangundangan Sebagaimana telah diubah dengan Undang-Undang Republik Indonesia Nomor 12 Tahun 2011 tentang Pembentukan Peraturan Perundang-Undangan.
2. Peraturan Daerah kabupaten/kota dibuat oleh dewan perwakilan rakyat daerah kabupaten/kota bersama bupati/walikota;

3. Peraturan Desa/peraturan yang setingkat, dibuat oleh badan perwakilan desa atau nama lainnya bersama dengan kepala desa atau nama lainnya.

Penjelasan Pasal 7 ayat (2) huruf a menyatakan bahwa termasuk dalam jenis Peraturan Daerah Provinsi adalah Qanun yang berlaku di Daerah Provinsi Nanggroe Aceh Darussalam dan Perdasus serta Perdasi yang berlaku di Provinsi Papua.

Berdasarkan ketentuan tersebut jelas bahwa Qanun Aceh dan Qanun Kabupaten/Kota merupakan peraturan perundang-undangan sejenis Peraturan Daerah yang secara khusus hanya berlaku di Provinsi Aceh, sebab kesitimewaan dan kekhususannya sebagai daerah otonomi khusus Pemerintahan Aceh. Begitu pula Peraturan Daerah Khusus merupakan peraturan perundang-undangan sejenis Peraturan Daerah yang secara khusus hanya berlaku di Provinsi Papua sebab keistimewaan dan kekhususannya sebagai daerah otonomi khusus Provinsi Papua. Oleh karena Peraturan Daerah Khusus dan Qanun merupakan peraturan perundangundangan yang sejenis dengan Peraturan Daerah pada umumnya tentunya Peraturan Daerah Khusus dan Qanun memiliki kedudukan yang setingkat dengan Peraturan 
Daerah. $^{11}$

Qanun dibedakan menjadi Qanun Aceh dan Qanun Kabupaten/Kota. Qanun Aceh berlaku di tingkat Provinsi dan memiliki kedudukan setingkat yang dengan Peraturan Daerah Provinsi. Qanun Kabupaten/Kota berlaku di tingkat Kabupaten/Kota dan memiliki kedudukan yang setingkat dengan Peraturan Daerah Kabupaten/Kota. Berbeda halnya dengan Peraturan Daerah Khusus dan Qanun hanya terdapat pada tingkatan Provinsi dan kedudukannya setingkat dengan Peraturan Daerah Provinsi.

Berdasarkan uraian tersebut, Peraturan Daerah Khusus dan Qanun merupakan peraturan perundang-undangan yang sejenis dan setingkat dengan Peraturan Daerah sebagai bagian integral dari sistem hukum nasional dan hirarki peraturan perundang-undangan. Dengan demikian, sesuai dengan asas hirarki peraturan perundang-undangan maka Peraturan Daerah Khusus dan Qanun tidak boleh bertentangan dengan peraturan perundangundangan yang lebih tinggi, kecuali diatur lain oleh undang-undang otonomi khusus terkait. Hal ini sesuai dengan asas umum peraturan perundang-undangan yang menyatakan bahwa peraturan perundangundangan yang bersifat khusus dapat

${ }^{11}$ Zainuddin Ali, Hukum Islam : Pengantar Hukum Islam Di Indonesia, (Jakarta: Sinar Grafika, 2008), hlm. 100. menyampingkan peraturan perundangundangan yang bersifat umum (lex specialis derogat lex generalis). Dalam UndangUndang Nomor 11 Tahun 2006 tentang Pemerintahan Aceh hal tersebut ditegaskan dalam Pasal 235 ayat (2) yang menyatakan bahwa Pemerintah dapat membatalkan qanun yang bertentangan dengan kepentingan umum; antarqanun; dan peraturan perundang-undangan yang lebih tinggi, kecuali diatur lain dalam undangundang ini.

Penggunaan istilah Peraturan Daerah Khusus dan Qanun ini sebagai nama lain dari Peraturan Daerah sesuai dengan hal-hal khusus yang berkaitan dengan kondisi dan karakteristik daerah yang bersangkutan. Hal-hal khusus yang membedakan Peraturan Daerah Khusus dan Qanun dengan Peraturan Daerah, antara lain lembaga yang membentuk dan materi muatannya. Peraturan Daerah ditetapkan oleh Kepala Daerah setelah mendapat persetujuan bersama Dewan Perwakilan Rakyat Daerah. Berbeda dengan Peraturan Daerah pada umumnya, Qanun Aceh disahkan oleh Gubernur setelah mendapat persetujuan bersama dengan Dewan Perwakilan Rakyat Daerah Aceh, sedangkan Qanun Kabupaten/Kota disahkan oleh bupati/walikota setelah mendapat persetujuan bersama dengan Dewan Perwakilan Rakyat Daerah Kabupaten/Kota. 
Peraturan Daerah Khusus juga memiliki kekhususan yang membedakan dengan Peraturan Daerah pada umumnya. Peraturan Daerah Khusus dibuat dan ditetapkan oleh Dewan Perwakilan Rakyat Papua bersama-sama Gubernur dengan pertimbangan dan persetujuan Majelis Rakyat Papua. Aspek lain yang membedakan Peraturan Daerah Khusus dan Qanun dengan Peraturan Daerah pada umumnya adalah mengenai materi muatannya.

2. Materi Muatan Peraturan daerah Khusus dan Qanun

Peraturan Daerah Khusus dan Qanun sebagai Peraturan Daerah yang bersifat khusus memiliki kedudukan yang sama dengan Peraturan Daerah pada umumnya sebagai bagian dari sistem hukum nasional dalam kerangka hirarki peraturan perundang-undangan sebagaimana diatur dalam Undang-Undang Nomor 10 Tahun 2004.

Pengaturan materi muatan peraturan daerah selain tunduk kepada UndangUndang Nomor 10 tahun 2004 tentang Pembentukan Peraturan Perundangundangan juga tunduk kepada UndangUndang Nomor 32 Tahun 2004 tentang Pemerintahan Daerah sebagai undangundang yang lebih spesifik mengatur mengenai pemerintahan daerah. Bagi daerah yang berstatus sebagai daerah otonomi khusus tentunya pengaturan mengenai materi muatan daerah selain tunduk kepada kedua undang-undang tersebut, juga tunduk kepada undangundang otonomi khusus bagi daerah yang bersangkutan. ${ }^{12}$

Dengan demikian, materi muatan Qanun adalah materi muatan Peraturan Daerah pada umumnya kecuali diatur lain oleh Undang-Undang Nomor 11 Tahun 2006 tentang Pemerintahan Aceh dan ditambah dengan materi muatan yang diperintahkan oleh Undang-Undang Nomor 11 Tahun 2006 tentang Pemerintahan Aceh. Begitu pula materi muatan Peraturan Daerah Khusus adalah materi muatan Peraturan Daerah pada umumnya kecuali diatur lain oleh Undang-Undang Nomor 21 Tahun 2001 tentang Otonomi Khusus bagi Provinsi Papua dan ditambah dengan materi muatan yang diperintahkan oleh UndangUndang Nomor 21 Tahun 2001 tentang Otonomi Khusus bagi Provinsi Papua. ${ }^{13}$

Dengan demikian, untuk memahami apa saja materi muatan Peraturan Daerah Khusus dan Qanun terlebih dahulu harus dipahami materi muatan Peraturan Daerah secara umum sebagaimana diatur dalam Undang-Undang Nomor 10 Tahun 2004 dan Undang-Undang Nomor 32 Tahun 2004 beserta peraturan pelaksanaannya.

12 Ahmad Sukardja dan Mujar Ibnu Syarif, Tiga Kategori Hukum Syariat, Fikih, dan Qanun, (Jakarta: Sinar Grafika, 2012), hlm. 5.

${ }_{13}$ Undang-Undang Nomor 21 Tahun 2001 tentang Otonomi Khusus. 
Pasal 12 Undang-Undang Nomor 10 mengatur materi muatan Peraturan Daerah adalah seluruh materi muatan dalam rangka penyelenggaraan otonomi daerah dan tugas pembantuan, dan menampung kondisi khusus daerah serta penjabaran peraturan perundang-undangan yang lebih tinggi.

Di dalam Undang-undang Nomor 32 Tahun 2004 tentang Pemerintahan Daerah terdapat beberapa pasal yang mengatur mengenai materi muatan Peraturan Daerah. Ketentuan yang menjadi landasan bagi pengaturan materi muatan Peraturan Daerah ialah Pasal 10 yang terdiri atas 5 (lima) ayat. Pertama, Pemerintah Daerah menyelenggarakan urusan pemerintahan yang menjadi kewenangannya, kecuali urusan pemerintahan yang oleh UndangUndang ini ditentukan menjadi urusan Pemerintah. Kedua, Dalam menyelenggarakan urusan pemerintahan yang menjadi kewenangan daerah sebagaimana dimaksud pada ayat (1), pemerintahan daerah menjalankan otonomi seluas-seluasnya untuk mengatur dan mengurus sendiri urusan pemerintahan berdasarkan asas otonomi dan tugas pembantuan. Ketiga, Urusan pemerintahan yang menjadi urusan pemerintah sebagaimana dimaksud pada ayat (1) meliputi: (a). politik luar negeri; (b). pertahanan; (c). keamanan; (d). yustisi; (e). moneter dan fiskal nasional; dan (f). agama. Keempat, Dalam menyelenggarakan urusan pemerintahan sebagaimana dimaksud pada ayat (3), pemerintah menyelenggarakan sendiri atau dapat melimpahkan sebagian urusan pemerintahan kepada perangkat pemerintah atau Wakil Pemerintah di daerah atau dapat menugaskan kepada Pemerintahan Daerah dan/atau Pemerintahan Desa. Kelima, Dalam urusan pemerintah yang menjadi kewenangan pemerintah, di luar urusan pemerintahan sebagaimana dimaksud pada ayat (1), Pemerintah dapat: (a). menyelenggarakan sendiri sebagian urusan pemerintahan; (b). melimpahkan sebagian urusan pemerintahan kepada Gubernur selaku wakil Pemerintahahan; dan (c). menugaskan sebagian urusan kepada pemerintahan daerah dan/atau pemerintahan desa berdasarkan asas tugas pembantuan.

Ketentuan Pasal 10 Undang-Undang Nomor 32 Tahun 2004 tersebut merupakan aturan umum mengenai materi muatan Peraturan Daerah. Pasal 10 ayat (1) menentukan bahwa Pemerintah Daerah memiliki kewenangan yang sangat luas, kecuali kewenangan yang menyangkut urusan politik luar negeri, pertahanan, keamanan, yustisi, moneter dan fiskal nasional, dan agama yang ditetapkan sebagai kewenangan Pemerintah Pusat. Dalam menyelenggarakan urusan pemerintahan yang menjadi kewenangan daerah tersebut, pemerintahan daerah menjalankan otonomi seluas-seluasnya 
untuk mengatur dan mengurus sendiri urusan pemerintahan berdasarkan asas otonomi dan tugas pembantuan. Dengan demikian, materi muatan Peraturan Daerah mencakup aspek yang sangat luas yaitu seluruh materi yang berkaitan dengan urusan pemerintahan diluar 6 (enam) urusan yang menjadi kewenangan Pemerintah Pusat ditambah dengan tugas pembantuan yang diberikan oleh Pemerintah Pusat.

Selain 6 (enam) kewenangan yang ditentukan menjadi kewenangan pemerintah pusat tidak begitu saja dibagi habis menjadi kewenangan pemerintahan daerah. Pemerintah pusat masih memiliki kewenangan lainnya yang dibagi berdasarkan kriteria eksternalitas, akuntabilitas, dan efisiensi dengan memperhatikan keserasian hubungan antar susunan pemerintahan. Hal ini diatur dalam Pasal 11 sampai dengan 18 UndangUndang Nomor 32 Tahun 2004.

Saat ini, setelah disahkannya Peraturan Pemerintah Nomor 38 Tahun 2007 tentang Pembagian Urusan Pemerintahan antara Pemerintah, pemerintahan daerah Provinsi, dan Pemerintahan Daerah Kabupaten/Kota sudah terdapat pengaturan yang baku mengenai batasan-batasan kewenangan antara Pemerintah Pusat, Pemerintahan Daerah Provinsi, dan Pemerintahan Daerah Kabupaten/Kota. Dengan adanya Peraturan Pemerintah ini, maka daerah akan lebih mudah memahami urusan apa saja yang menjadi kewenangannya dan materi muatan apa yang perlu dibentuk menjadi suatu Peraturan Daerah. Selain materi muatan tersebut, di dalam Undang-Undang Nomor 32 Tahun 2004 juga terdapat ketentuan yang menyebutkan secara tegas hal-hal perlu diatur dalam suatu Peraturan Daerah, antara lain: Pembentukan kecamatan; Pembentukan kelurahan; Perubahan/ penyesuaian status desa menjadi kelurahan; Penetapan susunan organisasi perangkat daerah; Penetapan Rencana Pembangunan Jangka Panjang Daerah (RPJP Daerah) Rencana Pembangunan Jangka Menengah Daerah (RPJM Daerah); Anggaran Pendapatan dan Belanja Daerah, Perubahan Anggaran Pendapatan dan Belanja Daerah; Pertanggungjawaban pelaksanaan Anggaran Pendapatan dan Belanja Daerah; Pajak daerah dan retribusi daerah, Hasil pengelolaan kekayaan daerah yang dipisahkan; Insentif dan/atau kemudahan kepada masyarakat dan/atau investor dalam meningkatkan perekonomian daerah; Penetapan pembentukan, penggabungan, pelepasan kepemilikan, dan/atau pembubaran BUMD; Tata cara penyusunan rencana kerja dan anggaran satuan kerja perangkat daerah serta tata cara penyusunan dokumen pelaksanaan anggaran satuan kerja perangkat daerah; Tata ruang; Penyusunan, pelaksanaan, penatausahaan, pelaporan, pengawasan dan 
pertanggungjawaban keuangan; Kawasan perkotaan; Desa dan pembangunan kawasan pedesaan; Syarat lanjutan dan tata cara pemilihan kepala desa; Tugas dan kewajiban kepala desa dalam memimpin penyelenggaraan pemerintahan desa; dan Syarat dan tata cara penetapan anggota dan pimpinan badan permusyawaratan desa.

Materi muatan Qanun adalah materi muatan Peraturan Daerah pada umumnya ditambah dengan materi muatan yang diperintahkan oleh Undang-Undang Nomor 11 Tahun 2006 tentang Pemerintahan Aceh. Begitu pula materi muatan Peraturan Daerah Khusus adalah materi muatan Peraturan Daerah pada umumnya ditambah dengan materi muatan yang diperintahkan oleh Undang-Undang Nomor 21 Tahun 2001 tentang Otonomi Khusus bagi Provinsi Papua. Dalam Undang-Undang Nomor 11 Tahun 2006 telah ditentukan sebagai muatan Qanun Aceh, antara lainL Bendera daerah, lambang daerah, dan himne Aceh; Ketentuan lebih lanjut pelaksanaan syari'at Islam; Kewenangan dan hukum acara mahkamah syar'iah; Majelis Permusyawaratan Ulama; Wali Nanggroe; Lembaga adat, pemberdayaan adat, dan adat istiadat; Mukim dan gampong; Pembagian urusan pemerintahan yang berkaitan dengan syari'at Islam antara Pemerintahan Aceh dan Pemerintahan Kabupaten/Kota;Pelaksanaan keistimewaan Aceh yang antara lain meliputi: (a).
Penyelenggaraan kehidupan beragama dalam bentuk pelaksanaan syari'at Islam bagi pemeluknya di Aceh dengan tetap menjaga kerukunan hidup antarumat beragama, (b). Penyelenggaraan kehidupan adat yang bersendikan agama Islam, (c). Penyelenggaraan pendidikan yang berkualitas serta menambah materi muatan lokal sesuai dengan syari'at Islam, (d). Peran ulama dalam penetapan kebijakan Aceh; dan (e). Penyelenggaraan dan pengelolaan ibadah haji sesuai dengan peraturan perundang-undangan; dan Kewenangan Pemerintah Aceh tentang pelaksanaan Undang-Undang Nomor 11 Tahun $2006{ }^{14}$

\section{Dalam Undang-Undang Nomor 21} Tahun 2001 telah ditentukan sebagai materi muatan Peraturan Daerah Khusus, antara lain: Lambang daerah; Usaha-usaha perekonomian yang memanfaatkan sumber daya alam; Pengembangan suku-suku terisolasi, terpencil, dan terabaikan; dan Pelaksanaan pengawasan sosial (pengawasan yang dilakukan masyarakat terhadap pelaksanaan tugas mrp, dprd, gubernur dan perangkatnya dalam bentuk petisi, kritik, protes, saran, dan usul).

Dari uraian tersebut, materi muatan peraturan daerah yang bersifat khusus

14 Mardani, Hukum Islam: Kumpulan Peraturan tentang Hukum Islam di Indonesia, (Jakarta Prenada Media Group, 2013), hlm. 642. 
secara prinsip sama dengan materi muatan peraturan daerah sebagaimana ditentukan dalam Undang-Undang Nomor 10 Tahun 2004 dan Undang-Undang Nomor 32 Tahun 2004 selama tidak diatur lain oleh undang-undang otonomi khusus daerah terkait. Undang-Undang Nomor 21 Tahun 2001 dan Undang- Undang Nomor 11 Tahun 2006 sebagai lex specialis dapat mengatur lain dan menambahkan materi muatan tertentu sesuai dengan keistimewaan dan kekhususan daerah terkait.

\section{Keberadaan Peraturan Daerah Khusus dan Qanun Dalam Penyelenggaraan Kehidupan \\ Masyarakat}

Pada dasarnya keberadaan Peraturan Daerah Khusus memiliki peran penting sebagai salah satu wujud penyelenggaraan Pemerintahan Daerah Papua berdasarkan kewenangan otonomi khusus. Fungsi Peraturan Daerah Khusus tertuang dalam Undang-Undang Nomor 21 Tahun 2001 junto Peraturan Pemerintah Pengganti Undang-Undang Nomor 1 Tahun 2008 junto Undang-Undang Nomor 35 Tahun 2008 (Undang-Undang Otonomi Khusus) untuk melaksanakan pasal-pasal tertentu dalam Undang-Undang Otonomi Khusus. Berdasarkan Pasal 29 Undang-Undang Otonomi Khusus, Peraturan Daerah Khusus dibuat dan ditetapkan oleh Dewan Perwakilan Rakyat Papua (DPRP) bersama- sama Gubernur dengan pertimbangan dan persetujuan Majelis Rakyat Papua (MRP). Berbeda dengan Peraturan Daerah Khusus, Peraturan Daerah Provinsi (Perdasi) dibuat dan ditetapkan oleh DPRP dan Gubernur, tanpa persetujuan MRP. ${ }^{15}$

Pengaturan kewenangan antara Pemerintah dengan Pemerintah Provinsi Papua serta penerapan kewenangan tersebut di Provinsi Papua yang dilakukan dengan kekhususan tertuang dalam Pasal 4 Undang-Undang Otonomi Khusus. Pasal tersebut menyatakan bahwa kewenangan Provinsi Papua mencakup kewenangan dalam seluruh bidang pemerintahan, kecuali kewenangan bidang politik luar negeri, pertahanan keamanan, moneter dan fiskal, agama, dan peradilan serta kewenangan tertentu di bidang lain yang ditetapkan sesuai dengan peraturan perundangundangan. Selain itu dalam rangka pelaksanaan Otonomi Khusus, Provinsi Papua diberikan kewenangan khusus berdasarkan Undang-Undang Otonomi Khusus yang diatur lebh lanjut dengan Peraturan Daerah Khusus dan Peraturan Daerah Provinsi. ${ }^{16}$

Dasar konstitusionalitas pembentukan peraturan-peraturan di daerah merujuk

\footnotetext{
${ }^{15}$ A. Sakti R.S. Rakia, “Kewenangan Khusus Majelis Rakyat Papua Terhadap Pembentukan Perdasus," Jurnal Justisi, Vol. 7, No. 1, 2021, Universitas Muhammadiyah Sorong, hIm. 15.

${ }^{16}$ Ibid., hlm. 18.
} 
Pasal 18 ayat (6) Undang-Undang Dasar

Negara Republik Indonesia Tahun 1945, yakni: Pemerintahan daerah berhak menetapkan peraturan daerah dan peraturan-peraturan lain untuk melaksanakan otonomi dan tugas pembantuan. Frasa "dan peraturanperaturan lainnya" dalam Pasal 18 ayat (6) tersebut memberikan atribusi kewenangan kepada pemerintahan daerah untuk membentuk peraturan lainnya selain Peraturan Daerah yang jenis dan bentuknya disesuaikan dengan istilah-istilah beragam di tingkat Provinsi maupun Kabupaten/Kota.

Berdasarkan Pasal 1 huruf I UndangUndang Otonomi Khusus, Peraturan Daerah Khusus dan Peraturan Daerah Provinsi Papua dalam rangka pelaksanaan pasalpasal tertentu dalam Undang-Undang Otonomi Khusus. Hal ini tertuang dalam Peraturan Menteri Dalam Negeri Nomor 120 Tahun 2018 yang menyebutkan bahwa Peraturan Daerah Khusus yang disingkat Perdasus adalah Peraturan Daerah Provinsi Papua dan Provinsi Papua Barat dalam rangka pelaksanaan pasal tertentu dalam Undang-Undang Otonomi Khusus bagi Papua dan Papua Barat. Mekanisme pembentukan peraturan di daerah tunduk pada ketentuan Undang-Undang Nomor 12 tahun 2011, sebagaimana telah diubah dengan Undang-Undang Nomor 15 Tahun 2019 tentang Perubahan Atas Undang-
Undang Nomor 12 tahun 2011. ${ }^{17}$

Secara etimologis, kata qanun berasal dari Bahasa Yunani, kanon, yang berarti untuk memerintah, tolok ukur atau mengukur. Seiring luasnya penggunaan dalam tradisi formal artinya meluas menjadi, aturan baku yang diterima oleh sebuah majelis. Secara terminologis, qanun bermakna sebagai bentuk hukum nasional yang telah menjadi legal-formal. Pengertian Qanun dalam Kamus Besar Bahasa Indonesia dikenal dengan nama: Kanun, artinya: undang-undang, peraturan, kitab undang- undang, hukum dan kaidah. ${ }^{18}$ Adapun pengertian Qanun menurut kamus Bahasa Arab adalah undang-undang, kebiasaan atau adat. ${ }^{19}$

Jadi dapat disimpulkan bahwa pengertian dari Qanun adalah suatu peraturan perundang-undangan atau aturan hukum yang berlaku di suatu daerah (dalam hal ini di Nanggroe Aceh Darussalam).

Penyebutan Qanun terhadap suatu aturan hukum atau untuk penamaan suatu adat telah lama dipakai dan telah menjadi bagian dari kultur adat dan budaya Aceh. Aturan-aturan hukum dan juga adat yang dikeluarkan oleh Kerajaan Aceh banyak yang dinamakan dengan Qanun. Qanun

${ }^{17}$ Ibid., hlm. 20.

18 Pusat Pembinaan Dan Pengembangan Bahasa Departemen Pendidikan Dan Kebudayaan, Kamus Besar Bahasa Indonesia, (Jakarta: Balai Pustaka, 2002), hlm. 442.

19 Mahmud Yunus, Kamus Arab-Indonesia, (Jakarta: Hidakarya Agung, 1989), hlm. 357. 
biasanya berisi aturan-aturan syariat Islam yang telah beradaptasi menjadi adat istiadat Aceh. Ketentuan tentang Qanun terdapat di dalam Undang-Undang Nomor 11 Tahun 2006 tentang Pemerintahan Aceh, yaitu: ${ }^{20}$ (1) Qanun Aceh adalah peraturan perundang-undangan sejenis peraturan daerah provinsi yang mengatur penyelenggaraan pemerintahan dan kehidupan masyarakat Aceh. ${ }^{21}$ (2) Qanun kabupaten/kota adalah peraturan perundang-undangan sejenis peraturan daerah kabupaten/kota yang mengatur penyelenggaraan pemerintahan dan kehidupan masyarakat kabupaten/kota di Aceh. $^{22}$

Dari ketentuan kedua pasal tersebut, terlihat maksud dari Qanun dapat disamakan dengan Peraturan Daerah di Provinsi lain di Indonesia, tetapi pada dasarnya pemahaman Qanun yang disamakan dengan Peraturan Daerah sesungguhnya tidaklah tepat. Qanun merupakan suatu peraturan perundangundangan yang diberlakukan di Nangroe Aceh Darussalam yang isinya harus berlandaskan syariat Islam yang menjadi kekhususan dari Nangroe Aceh Darussalam.

20 Kata sejenis dapat diartikan dengan sebangsa, semacam atau serupa. Pusat Pembinaan Dan Pengembangan Bahasa Departemen Pendidikan Dan Kebudayaan, Kamus Besar..., Op.,Cit., hlm. 411.

\footnotetext{
21 Pasal 1 angka 21 Undang-Undang Nomor 11 Tahun 2006.

${ }^{22}$ Ibid.
}

Hal ini berbeda dengan daerah lain yang aturan-aturan dalam Peraturan Daerahnya tidak harus berlandaskan ajaran-ajaran Islam. Selain itu, berbeda dengan Peraturan Daerah lainnya di Indonesia, aturan-aturan Qanun dapat berisikan aturan-aturan hukum tentang hukum acara material dan formil di Mahkamah Syar'iah.

Jadi pengertian Qanun tidaklah sama dengan Peraturan Daerah, sebab isi dari Qanun haruslah berlandaskan pada asas keislaman atau tidak boleh bertentangan dengan syari'at Islam. Akan tetapi, dalam hal hierarki hukum di Indonesia, sesuai dengan ketentuan Undang-Undang Nomor 10 Tahun 2004 tentang Pembentukan Peraturan Perundang- undangan, kedudukan Qanun dipersamakan dengan Peraturan Daerah di daerah lainnya. Menurut Undang-Undang Nomor 10 Tahun 2004 bahwa jenis dan hierarki peraturan perundang-undangan sebagai berikut: Undang-Undang Dasar Negara Republik Indonesia Tahun 1945, UndangUndang/Peraturan Pemerintah Pengganti Undang-Undang, Peraturan Pemerintah, Peraturan Presiden dan Peraturan Daerah. Dalam Penjelasan Pasal 7 bahwa termasuk dalam jenis peraturan daerah provinsi adalah Qanun yang berlaku di Daerah Provinsi Nanggroe Aceh Darussalam dan Peraturan Daerah Khusus dan Peraturan Daerah Provinsi yang berlaku di Provinsi 
Papua. $^{23}$

Berdasarkan ketentuan tersebut, maka kedudukan Peraturan Daerah Khusus dan Qanun diakui dalam hierarki perundangundangan Indonesia dan dipersamakan dengan Peraturan Daerah. Pemahaman dalam Undang-Undang Nomor 10 Tahun 2004 ini bisa saja diterima dalam hal kedudukan Peraturan Daerah Khusus dan Qanun. Pemahaman ini akan lebih mempermudah Pemerintah Pusat dalam melakukan pengawasan dan pembinaan terhadap daerah, terutama yang berhubungan dengan pembentukan suatu kebijakan daerah. Hanya saja tetap harus diperhatikan tentang kekhususan yang diberikan Pusat terhadap Nanggroe Aceh Darussalam. Contohnya saja, berdasarkan kekhususan yang di berikan Pusat kepada Nanggroe Aceh Darussalam, maka DPR Aceh dapat mensahkan Qanun tentang jinayat atau peradilan pidana Islam sebagai hukum acara di Mahkamah Syar'iah. Hanya saja memang produk dari Qanun ini harus memenuhi syarat-syarat yang harus dipenuhi oleh Pemerintahan Aceh seperti tidak boleh bertentangan dengan: aqidah, syar'iyah dan akhlak yang dalam penjabarannya meliputi: ibadah, ahwal alsyakhshiyah (hukum keluarga), muamalah (hukum perdata), jinayah (hukum pidana), qadha' (peradilan), tarbiyah (pendidikan),

\footnotetext{
${ }^{23}$ Pasal 7 Undang-Undang Nomor 10 Tahun 2004.
}

dakwah, syiar dan pembelaan Islam. $^{24}$ Kebijakan ini tentu tidak diperbolehkan dibuat oleh perda-perda lainnya di Indonesia.

Adapun kedudukan Qanun terdapat di dalam peraturan perundang-undangan, antara lain: Undang-Undang Nomor 18 Tahun 2001 tentang Otonomi Khusus Bagi Provinsi Daerah Istimewa Aceh Sebagai Provinsi Nanggroe Aceh Darussalam. Kedudukan Qanun terdapat di dalam Pasal 1 angka 8 yang mengatakan bahwa Qanun Provinsi Nanggroe Aceh Darussalam adalah peraturan daerah sebagai pelaksanaan undang-undang di wilayah Provinsi Nanggroe Aceh Darussalam dalam rangka penyelenggaraan otonomi khusus; Undang-Undang Nomor 10 Tahun 2004 tentang Pembentukan Peraturan Perundang undangan. Penjelasan Pasal 7 ayat (2) a, yang mengatakan bahwa termasuk dalam jenis peraturan daerah provinsi adalah Qanun yang berlaku di daerah Nanggroe Aceh Darussalam dan perdasus serta perdasi yang berlaku di propinsi Papua; Undang-Undang Nomor 11 Tahun 2006 tentang Pemerintahan Aceh. Pasal 21 dan 22 menyatakan bahwa Qanun adalah peraturan perundang-undangan sejenis peraturan daerah yang mengatur penyelenggaraan pemerintahan dan kehidupan masyarakat Aceh.

${ }^{24}$ Lihat ketentuan dalam Pasal 125 UndangUndang Nomor 11 Tahun 2006. 
Pasal 1 angka 8 dirumuskan sebagai Qanun Propinsi Nanggroe Aceh Darussalam adalah Peraturan Daerah sebagai pelaksaan undang-undang di wilayah Propinsi Nanggroe Aceh Darussalam dalam rangka penyelenggaraan otonomi khusus. $^{25}$ Qanun merupakan peraturan daerah untuk melaksanakan otonomi khusus yang dapat mengenyampingkan peraturan perundangundangan yang lain dengan mengikuti asas lex specialis doraget lex generalis. Dengan demikian, qanun adalah peraturan daerah yang setingkat dengan peraturan pemerintah untuk pelaksanaan otonomi khusus di daerah Aceh, atau paling kurang merupakan peraturan daerah plus sebab dapat melaksanakan undang-undang secara langsung dan merupakan peraturan daerah yang dapat mengenyampingkan peraturan lain berdasar asas peraturan khusus mengenyampingkan peraturan umum. ${ }^{26}$

Undang-Undang Nomor 11 Tahun 2007 tentang Pemerintahan Aceh merupakan tatanan hukum dalam sistem hukum dan sistem perundang-undangan

25 Mohammad Daud Ali, Kedudukan Dan Pelaksanaan Hukum Islam Dalam Tatanan Masyarakat Indonesia, (Jakarta: Logos Wacana Ilmu, 1998), hlm 45-47.

26 Al Yasa' Abubakar, Syariat Islam Di Propinsi Nanggroe Aceh Darussalam, Edisi Kelima, (Banda Aceh: Dinas Syariat Islam Propinsi NAD, 2008), hlm 69. nasional. $^{27}$ Dalam Pasal 1 angka 21 Undang-Undang Nomor 11 Tahun 2006 menentukan bahwa Qanun Aceh adalah peraturan perundang-undangan sejenis peraturan daerah provinsi yang mengatur penyelenggaraan pemerintahan dan kehidupan masyarakat Aceh. ${ }^{28}$ Sementara Pasal 233 ayat (1) menyatakan bahwa Qanun dibentuk dalam rangka penyelenggaraan Pemerintahan Aceh, pemerintahan kabupaten/ kota, dan penyelenggaraan tugas pembantuan.

Pasal 136 ayat (2) Undang-Undang Nomor 32 Tahun 2004 menegaskan bahwa peraturan daerah dibentuk dalam rangka penyelenggaraan otonomi daerah provinsi/kabupaten/kota dan tugas pembantuan. Kemudian ayat (3) pasal yang sama ditentukan bahwa peraturan daerah merupakan penjabaran dari peraturan perundang-undangan yang lebih tinggi dengan memperhatikan ciri khas masingmasing daerah.

Pasal 1 angka 7 Undang-Undang No. 10 Tahun 2004 menentukan bahwa peraturan daerah adalah peraturan perundang-undangan yang dibentuk oleh Dewan Perwakilan Rakyat Daerah dengan persetujuan bersama Kepala Daerah. Kemudian Pasal 12 Undang-Undang Nomor 10 Tahun 2004 menentukan bahwa materi muatan peraturan daerah adalah

27 Undang-Undang Nomor 11 Tahun 2007 tentang Pemerintahan Aceh

28 Undang-Undang Nomor 11 Tahun 2006 tentang Pemerintahan Aceh. 
seluruh materi muatan dalam rangka penyelenggaraan otonomi daerah dan tugas pembantuan, dan menampung kondisi khusus daerah serta penjabaran lebih lanjut peraturan perundang- undangan yang lebih tinggi.

Mencermati hal tersebut, jelas bahwa Peraturan Daerah Khusus dan Qanun merupakan bagian dari sistem perundangundangan nasional. Oleh karena itu, norma atau kaedah hukum materi muatan dalam Peraturan Daerah Khusus dan Qanun merupakan sub sistem dari sistem hukum nasional, sebab wilayah berlakunya adalah khusus atau bersifat lokal. Walaupun berlakunya pada wilayah khusus, akan tetapi penegakan hukumnya tetap melibatkan institusi dalam sistem peradilan nasional.

\section{PENUTUP}

Berdasarkan ketentuan tersebut, jelas bahwa Peraturan Daerah Khusus dan Qanun merupakan peraturan perundang-undangan sejenis Peraturan Daerah yang secara khusus hanya berlaku di Provinsi Papua dan Aceh, sebab kesitimewaan dan kekhususannya sebagai daerah otonomi khusus Pemerinatah Papua dan Pemerintahan Aceh. Oleh karena Peraturan Daerah Khusus dan Qanun merupakan peraturan perundang-undangan yang sejenis dengan Peraturan Daerah, maka kedudukan Peraturan Daerah Khusus dan Qanun setingkat dengan Peraturan Daerah.
Berbeda halnya dengan Qanun, Peraturan Daerah Khusus hanya terdapat pada tingkatan Provinsi dan kedudukannya setingkat dengan Peraturan Daerah Provinsi. Sementara Qanun dibedakan menjadi Qanun Aceh dan Qanun Kabupaten/Kota. Qanun Aceh berlaku di tingkat Provinsi dan memiliki kedudukan setingkat yang dengan Peraturan Daerah Provinsi. Qanun Kabupaten/Kota berlaku di tingkat Kabupaten/Kota dan memiliki kedudukan yang setingkat dengan Peraturan Daerah Kabupaten/Kota.

Dalam Undang-Undang Nomor 10 Tahun 2004 menyatakan bahwa jenis dan hierarki peraturan perundang- undangan sebagai berikut: Undang-Undang Dasar Negara Republik Indonesia Tahun 1945, UndangUndang/Peraturan Pemerintah Pengganti Undang-Undang, Peraturan Pemerintah, Peraturan Presiden dan Peraturan Daerah. Dalam Penjelasan Pasal 7 menegaskan bahwa termasuk dalam jenis peraturan daerah provinsi adalah Qanun yang berlaku di Daerah Provinsi Nanggroe Aceh Darussalam dan Peraturan Daerah Khusus serta Peraturan Daerah Provinsi yang berlaku di Provinsi Papua.

\section{DAFTAR PUSTAKA}

A. Sakti R.S. Rakia, "Kewenangan Khusus Majelis Rakyat Papua Terhadap Pembentukan Perdasus," Jurnal Justisi, Vol. 7, No. 1, 2021, Universitas Muhammadiyah Sorong.

Ahmad Sukardja dan Mujar Ibnu Syarif. 2012. Tiga Kategori Hukum Syariat, Fikih, dan Qanun. Jakarta: Sinar Grafika. 
Al Yasa' Abubakar. 2008. Syariat Islam Di Propinsi Nanggroe Aceh Darussalam. Edisi Kelima. Banda Aceh: Dinas Syariat Islam Propinsi NAD.

Jimly Asshiddiqie. 2002. Konsolidasi Naskah UUD 1945 Setelah Perubahan Keempat. Jakarta: Pusat Studi Hukum Tata Negara, FH UI.

Mahmud Yunus. 1989. Kamus ArabIndonesia. Jakarta: Hidakarya Agung.

Mardani. 2013. Hukum Islam: Kumpulan Peraturan tentang Hukum Islam di Indonesia. Jakarta Prenada Media Group.

Mohammad Daud Ali. 1998. Kedudukan Dan Pelaksanaan Hukum Islam Dalam Tatanan Masyarakat Indonesia. Jakarta: Logos Wacana Ilmu.

Muhammad Alim, "Perda Bernuansa Syariah Dan Hubungannya Dengan Konstitusi”, Jurnal Hukum Ius Quia Iustum, FH UII, No.1 Vol. 17 Januari 2010.

Pusat Pembinaan Dan Pengembangan Bahasa Departemen Pendidikan Dan Kebudayaan. Kamus Besar Bahasa Indonesia. Jakarta: Balai Pustaka.

Soerjono Soekanto dan Sri Mamudji. 2003. Penelitian Hukum Normatif, Suatu Tinjauan Singkat. Jakarta: Raja Grafindo.

Zainuddin Ali. 2008. Hukum Islam : Pengantar Hukum Islam Di Indonesia. Jakarta: Sinar Grafika.

Undang-Undang Dasar Negara Republik Indonesia Tahun 1945

Undang-Undang Nomor 10 Tahun 2004 tentang Pembentukan Peraturan Perundang-undangan Sebagaimana telah diubah dengan UndangUndang Republik Indonesia Nomor 12 Tahun 2011 Tentang Pembentukan Peraturan Perundang-Undangan

Undang-Undang Nomor 11 Tahun 2006 tentang Pemerintahan Aceh
Undang-Undang Nomor 11 Tahun 2007 tentang Pemerintahan Aceh

Undang-Undang Nomor 18 Tahun 2001 tentang Otonomi Khusus bagi Provinsi Daerah Istimewa Aceh diganti dengan Undang-Undang Nomor 11 Tahun 2006 tentang Pemerintahan Aceh

Undang-Undang Nomor 21 Tahun 2001 tentang Otonomi Khusus bagi Propinsi Papua 